\title{
DEVELOPING TEACHER COMPETENCIES THROUGH THE OPEN AND DISTANCE LEARNING APPROACH IN ZIMBABWE
}

\author{
J. Mswazie \\ Department of Curriculum Studies \\ Zimbabwe Open University \\ Masvingo, Zimbabwe \\ e-mail: joswazi@yahoo.com
}

\section{S. Blignaut}

School of Education and Research Engagement

Nelson Mandela University

Port Elizabeth, South Africa

e-mail: sylvan.blignaut@mandela.ac.za

\section{ABSTRACT}

The main purpose of the study was to gain insights into the effectiveness of the open and distance learning approach (ODLA) as an empowering tool in upgrading rural teachers' professionalism. The data to address the problem was collected by means of a case study methodology. The results of the study indicate that female teachers involved in the study perceive the ODLA to be enabling in several respects. Firstly, the ODLA provided rural teachers with the flexibility and opportunities to switch careers midway. Secondly, the ODLA provided female teachers with new professional knowledge, skills and competences with minimal disruptions to their family, social and work commitments. Thirdly, the ODLA was regarded as cost effective in terms of access, affordability, effort and time management. In light of the above, this study calls for further comparative studies of ODLA to other teacher education models in improving teacher proficiencies in resourcestressed environments.

Key words: developing, teacher competences, ODLA, Zimbabwe

\section{INTRODUCTION}

Worldwide, the utilisation of the open and learning approach (ODLA) as a transformational strategy is linked to the flexible design elements of this innovation. According to the United Nations Education Scientific and Cultural Organization (UNESCO) (2002), the ODLA has been particularly effective in the retaining and upgrading of teacher qualifications. In Nigeria, the ODLA has been said to have trained or retrained over two million primary teachers since 1976. Currently the upgrading program has an enrolment of 150000 teachers.

The UNESCO Institute for Statistics (UNESCO 2009) indicates that worldwide there is a critical shortage of teachers particularly in developing countries if the need for universal 
schooling is to be met. According to this report, countries in Sub-Saharan Africa are facing the greatest need in terms of the number of teachers required to meet the goal of Education for All by the year 2015. The shortfall with regard to the number of teachers needed in Sub-Saharan Africa has been put at 1.2 million teachers (Danaher 2010). Against this backdrop, there has been increasing pressure on teacher education institutions to recruit and produce more competent and proficient teachers to meet the goal of universal education for all. Contemporary research has, however, revealed that traditional teacher education institutions have neither the capacity nor the will to produce the volume and quality of teachers required (Daniel 2010; Danaher 2010; Daniel 2010) believes that teacher shortages can be effectively addressed by adopting the Open and Distance Learning Approach (ODLA) particularly in teacher upgrading programmes. He has this to say on the matter:

"This is where ODL comes into its own. It not only enables in-service teacher education to take place in the schools, but also, through the growing use of information and communication technologies (ICT), it makes possible the creation of virtual communities of practice in which working teachers can learn from experienced teachers and from each other." (Daniel 2010, v).

Daniel (2008) further argues that the ODLA, as a technology, has been able to reconfigure successfully the eternal triangle of cost, access and high quality. The key advantages of ODLA include, among others, its flexibility and adaptability to various educational contexts (UNESCO 2007; Daniel 2008).

The literature presented above provides useful insights into reasons why the ODLA has been adopted in different contexts worldwide. However, gaps in knowledge still remain in respect of the reasons why adult learners, in particular female teachers with very tight work and family commitments prefer to enrol with the ODLA given the controversies and uncertainty surrounding ODLA provision. The following section examines two theoretical constructs and special education programme guidelines which provided the theoretical and conceptual framework for conducting the study.

\section{LITERATURE REVIEW AND THEORETICAL FRAMEWORKS}

Doyle and Ponder's (1977) construct of the practicality ethic in adult learner's decision making provides a useful conceptual framework for understanding participant responses to the ODLA in Zimbabwe. According to Doyle and Ponder (1977), teachers' decision-making is governed by the practicality ethic. Doyle and Ponder $(1977,1,7)$ define the practicality ethic as " $\ldots$ the decision-making processes which appear to underlie teachers' reactions to change proposals or ... the taken-for-granted world of the teacher". The practicality ethic is constituted of three 
concerns, namely instrumentality, congruence and cost.

Instrumentality refers to procedural clarity of the innovation in the context of application. According to Doyle and Ponder $(1977,7)$ : "Statements of principle or specification are not practical because they lack the procedural referents". Congruence relates to teachers' assessment of the innovation in relation to their own context or situations whereas cost refers to "... a ratio between the amount of return and the amount of investment" (Doyle and Ponder $1977,8)$. Fullan $(1991,129)$ conceptualises cost in relation to an innovation as “... personal costs in time, energy, and threat to sense of adequacy, with no evidence of benefit in return ...".

In the context of this study, Doyle and Ponder's formulation of the practical concerns in teacher decision making is particularly useful in trying to assess the two participants' motivation to study through the ODLA irrespective of the general scepticism surrounding qualifications obtained through distance education. What tangible benefits can be derived from ODLA programmes? What are the costs in terms of physical and mental effort to obtain an ODL qualification? These questions provided a useful frame for investigating the participants' motives for enrolling through the ODLA (see Tables 1 to 5).

Similarly, the skill development programme for Special Education teachers suggested by the Pennsylvania Special Education program guidelines (Pennyslvania Department of Education 2006) prescribes a set of skills and competencies which Special Education should have in order to be capable of managing their classes effectively. Among the key skills are the following:

- Observation skills to sharpen teachers' perception of children's variations in behavior and situations;

- Appreciation of the educational needs of children with different types of disabilities;

- Understanding of the practical actions needed to meet the unique requirements of a disabled child, and

- Awareness and appreciation of available support services to teachers and disabled students. (Pennsylvania Department of Education 2006, 14-26).

To sum up, the Practicality Ethics Theory (Doyle and Ponder 1977) and the Pennsylvania Special Education program guidelines (Pennsylvania Department of Education 2008) provided the theoretical and conceptual framework for conducting the study.

\section{PURPOSE OF THE STUDY}

This study serves several purposes. First, the study seeks to determine motivations which drive 
female rural-based primary school teachers to upgrade their professional qualifications through the ODLA. Second, but more importantly, this study seeks to gain insights into the impacts of a selected ODLA program in terms of its empowerment and transformational benefits. This information is critical not only in understanding the attractiveness of the ODLA to rural teachers, but as a potential resource for producing an adequate supply of teachers to meet the United Nations Millennium Development Goal for Universal Primary Education for all, by the year 2015.

\section{OBJECTIVES OF THE STUDY}

More precisely, the objectives of this study are as follows:

- Determine the key factors attracting female teachers to seek professional upgrading through the ODLA, and

- Assess the worth and relevancy of the knowledge and skills imparted by the Special Education Degree (SPED) program both to the teacher professional development.

\section{SIGNIFICANCE OF STUDY}

Consistent with the above objectives, this study is of value to a number of educational stakeholders. To policy formulators and the decision-makers in government and policy-making roles, this study will undoubtedly shed light on the desirability and feasibility of the ODLA in producing quality teachers, cost-effectively and efficiently. It has become an imperative for countries in Sub-Saharan Africa to develop alternative and sustainable teacher professional development models in view of the depressed and turbulent socio-economic environments in this region.

To teacher educators and trainers, this study would hopefully provide useful insights and lessons into strategies for designing and delivering high impact teacher education programs which resonate with prospective students. Recent studies by Mswazie (2013) and Mudyahoto and Mswazie (2013) had revealed that teacher education policy implementation in Zimbabwe was moribund and urgently in need of reform.

\section{PROBLEM STATEMENT}

In Zimbabwe, endless controversies and heated public debates have arisen in respect of the quality and relevancy of qualifications offered through the ODLA. Against this background, this study sought to determine specific aspects of the ODLA which enticed or lured rural-based female teachers to opt for the ODLA despite lingering doubts about the quality and relevancy of qualifications obtained through this method. 


\section{RESEARCH QUESTIONS}

The following questions were regarded as constituting aspects of the problem to be investigated.

1. Which design and operational aspects attract and motivate rural teachers to opt for the ODLA to upgrade their professional qualifications?

2. Which new professional knowledge, skills and competencies did participants gain from the SPED degree program?

\section{METHOD}

The data to address the above questions was obtained through interviews with two female teachers. The semi-structured interview constituted the main instrument in the data collection process. It constituted the principal tool for probing deeper into the participants underlying motivations for enrolling with the ODLA and to determine the knowledge, skills and competences gained from the program (see Tables 1-6). Cumulatively, the data collected through the interview methods were used to address the three research questions of the study.

\section{PARTICIPANTS}

Two women participants (Participants D and E) were identified through the snow ball method from among the alumni of the Zimbabwe Open University (ZOU) who had completed the SPED program at the Masvingo Regional Campus (MRC). Each of these two female teachers had a unique case to tell about the joy and tears of studying through the ODLA. Participant D was purposively selected for the following important reason. She was chosen because her bio-profile matched that of the typical mainstream learner at the Zimbabwe Open University (ZOU). According to Mugadzaweta and Benza (1999), a typical ODLA student is a mature adult, married and aged between 35 to 45 years. His/her highest school leaving certificate is the "O" level school certificate and has competing work and family commitments. Most of these students work in rural schools under extreme conditions with no contact or access to support services such as a library.

Participant E had an interesting story to tell about the ODLA. She is a single mother of one who raised herself from a primary school teacher to a university lecturer. After 18 years as a primary school teacher, Participant E initially enrolled for a Bachelor of Education degree in English and Communication with the ZOU. Her motivation was to become a secondary school teacher which in Zimbabwe has a higher status than primary (Mswazie 2013). When the SPED program came on stream, Participant E realized the market potential the new program offered. 
But because of the lingering questions surrounding ODLA provision, she decided to enrol for a fulltime SPED at a local conventional university. She is now a lecturer at a local university. These two participants were found to be suitable and useful sources of quality information to address and unpack the unresolved problem in respect of the quality and relevancy of the ODLA as an empowerment and transformational tool.

\section{INSTRUMENTATION}

The semi-structured interview questions constituted the main tool for data collection. It was used to probe deeper and wider issues related to participants' motivation to enroll with the ODLM, the form and content of skills and competencies gained from the program studied (see Tables 3-5) and also potential weaknesses in the design and delivery of the program (see Table $6)$.

\section{PROCEDURE}

After obtaining the consent of the participants to be involved in the study, the data collection processes commenced in phased sequences indicated in Tables 1-6. Since one of the participants teaches at a school in the rural areas and the other is now lecturing at a local university in Masvingo town, the interviews took place over weekends particularly on Saturdays when they rejoined their families and were free from other social engagements. Generally, the interview sessions would last between 40-60 minutes depending on the availability of time. The data collected is displayed in Tables $1-6$ of this article.

\section{METHODS OF DATA ANALYSIS AND INTERPRETATION}

A number of theoretical constructs were used to analyse and interpret the collected data. The data collected to address the contextual and motivational issues prompting the participants to opt for the ODLA to upgrade their qualifications were analysed and interpreted in terms of Doyle and Ponder's (1977) Practicality Ethics Theory (see Tables 1 and 2). The data to determine and assess the quality and value of professional competences and skills acquired through the SPED program was analysed and interpreted utilizing the Pennyslvania Department of Education guidelines (2008) (see Tables 3-5).

\section{DATA PRESENTATION AND ANALYSIS}

Table 1 and 2 examine the key influences underpinning the participants' decisions to opt for the ODLA rather than the conventional university mode to upgrade their professional statuses whereas Tables 3 to 5 analyse specific competences gained from the programme. 
Table 1 identifies three broad categories of influences which have motivated the participants and other adult learners in similar situations to opt for the ODLA to upgrade their professional competencies. The first category relates to personal ambitions or aspirations of the participants that appear as one of the motivators driving the participants to opt for the ODLA. The quest for self-fulfilment and career advancement constituted a major motivator for registering for the ODLA programme as the following statement suggests: "I wanted to reach higher levels of my career for self-actualization" (see Table 1).

Table 1: Factors which attracted and motivated participants to opt for the ODLA

\begin{tabular}{|c|c|c|}
\hline Factor & Participant D & Participant E \\
\hline Admission criteria & $\begin{array}{l}\text { "I had 'O' level passes which did not } \\
\text { enable me to enrol with conventional } \\
\text { universities." }\end{array}$ & $\begin{array}{l}\text { "Some universities required a diploma } \\
\text { in SPED before enrolling for the } \\
\text { Bachelors' Degree. ZOU overlooked } \\
\text { that and accepted a certificate or } \\
\text { diploma in general education." }\end{array}$ \\
\hline Advertisements & $\begin{array}{l}\text { "The print media in general but state- } \\
\text { owned newspapers in particular } \\
\text { influenced my decision." }\end{array}$ & $\begin{array}{l}\text { "Pamphlets about degree programmes } \\
\text { offered by ZOU inspired me to } \\
\text { undertake the programme." }\end{array}$ \\
\hline Career advancement & $\begin{array}{l}\text { "I wanted to reach higher levels of my } \\
\text { career for self-actualization." } \\
\text { "I was ambitious to further my studies } \\
\text { but vacancies at the conventional } \\
\text { universities were limited." }\end{array}$ & $\begin{array}{l}\text { "I had been a primary school teacher } \\
\text { for } 18 \text { years, so I wanted to change my } \\
\text { professional status." }\end{array}$ \\
\hline $\begin{array}{l}\text { Distance to the regional } \\
\text { centre }\end{array}$ & $\begin{array}{l}\text { The regional centre was not very far } \\
\text { away from my school, so I could afford } \\
\text { to attend weekend school." }\end{array}$ & $\begin{array}{l}\text { "Distance affected me positively } \\
\text { because the ZOU centre is a walkable } \\
\text { distance from my home. So, I did not } \\
\text { encounter any travelling expenses for } \\
\text { registration, submission of assignments } \\
\text { or examination as distant or } \\
\text { conventional students experience." }\end{array}$ \\
\hline Financial considerations & $\begin{array}{l}\text { "... financial constraints played a hand } \\
\text { in my decision to enrol for (sic) ODL } \\
\text { and the ODLM lessen my burden as I } \\
\text { was paying in installments." }\end{array}$ & $\begin{array}{l}\text { "I knew full time conventional studies } \\
\text { would render me to half salary but } \\
\text { calling for more expenses. ODL helped } \\
\text { me to pay my fees in instalments and it } \\
\text { was less costly compared to } \\
\text { conventional fees." }\end{array}$ \\
\hline $\begin{array}{l}\text { Peer pressures/ZOU } \\
\text { alumni }\end{array}$ & $\begin{array}{l}\text { "... they argued that ODLM did not } \\
\text { interfere much with my social obligation } \\
\text { as a parent and breadwinner." }\end{array}$ & $\begin{array}{l}\text { "They had already acquired better } \\
\text { paying jobs. They also explained the } \\
\text { flexibility of the ODL as opposed to } \\
\text { campus learning, which I appreciated." }\end{array}$ \\
\hline Social considerations & $\begin{array}{l}\text { "The attainment of a higher qualification } \\
\text { would improve my social status and } \\
\text { financial status." }\end{array}$ & $\begin{array}{l}\text { "There were a number of beneficiaries } \\
\text { of ODL. They had better paying jobs. } \\
\text { They had uplifted their professional } \\
\text { status, others had even changed their } \\
\text { status and quality of life." }\end{array}$ \\
\hline Personal circumstances & $\begin{array}{l}\text { "My spouse influenced me to opt for the } \\
\text { ODL so as to remain on full salary." }\end{array}$ & $\begin{array}{l}\text { "I had a sister who had mental } \\
\text { retardation, so I wanted to learn more } \\
\text { about disabilities." }\end{array}$ \\
\hline Temporal considerations & $\begin{array}{l}\text { "As a classroom practitioner and a } \\
\text { parent with financial and social } \\
\text { responsibilities to look after, ODLA was } \\
\text { the only way out." }\end{array}$ & $\begin{array}{l}\text { "I wanted to attain a second degree, but } \\
\text { I knew I would not be granted study } \\
\text { leave, so I opted for ZOU." }\end{array}$ \\
\hline
\end{tabular}

The second broad category of influences revolves around the issue of accessibility to the programme. Accessibility assumes a number of meanings as Table 1 reveals. First, accessibility of ODLA programs may refer to flexible admission requirements as suggested by the following 
remark: "I had ' $\mathrm{O}$ ' level passes which did not enable me to enrol with conventional universities". Here the participant realises that her qualifications would not allow her access to conventional universities whose entry requirements are set higher than her "O" levels. Second, accessibility of the ODLA program relates to distances to be covered and transport costs implicated by enrolling for the program as indicated by the following comment: "The regional centre was not far from my school so I could afford to attend weekend school".

The third category of influences revolve around the issue of affordability in terms of cost, effort and time required to successfully complete the programme. Financial costs constitute a key influence determining the participant's involvement with the ODLA programme. The participant had this to say on the matter "... financial constraints played a hand in my decision to enrol with ODLA and the ODLA lessen my burden as I was paying in instalments" (see Table 1). From this statement it is clear that flexible payment (instalments) in combination with relatively low fees constituted an inducement for the participant to opt for the ODLA. In addition, the participant has this to say on the matter: "ODLA meant that I would continue with my career as a teacher, and the fees were relatively accessible".

Finally, time pressures stand out as another key factor influencing one of the participants to opt for the ODLA. She had this to say on the matter: "As a classroom practitioner and a parent with financial and social responsibilities to look after, ODLM was the only way out" (see Table 1).

The data in Table 2 suggest that participants' decisions to opt for the ODLA may have been strongly influenced by the instructional design and operational aspects of the ODLA. In particular, the following aspects, appropriate timing of the delivery of the study materials; home-based study and individualised counseling seem to be the main inducements. For the current Vice Chancellor of the ZOU, the self-study packages are intended to address and dispel misconceptions about the quality of ODLA tuition (Kurasha 2003). To the participants, the packages are valued because they enable one "... to study and continue working, management of one's time and being able to be close to one's family". More importantly "... they guide the student and focus the student on what to study" (see Table 2).

Table 2: Summary data of key attractions of the ODLA design and delivery elements (From interview with participants 19 January 2013)

\begin{tabular}{|l|l|l|}
\hline \multicolumn{1}{|c|}{ Program design element } & \multicolumn{1}{|c|}{ Participant D } & \multicolumn{1}{c|}{ Participant E } \\
\hline Admission requirements & $\begin{array}{l}\text { "Gives access to education to people } \\
\text { who might have been dis-advantaged } \\
\text { by unrealistic entry requirements by } \\
\text { conventional university programs." }\end{array}$ & $\begin{array}{l}\text { "Most people are legible to register } \\
\text { even those with minimal } \\
\text { qualifications like ordinary level." }\end{array}$ \\
\hline Home-based study & $\begin{array}{l}\text { "Advantages include being able to } \\
\text { study and continue working, } \\
\text { management of one's time and being } \\
\text { able to be close to one's family." }\end{array}$ & $\begin{array}{l}\text { "One can attend to social issues, } \\
\text { work requirements, community } \\
\text { activities and study." }\end{array}$ \\
\hline
\end{tabular}




\begin{tabular}{|c|c|c|}
\hline Program design element & Participant D & Participant E \\
\hline $\begin{array}{l}\text { Formulation of course } \\
\text { objectives }\end{array}$ & $\begin{array}{l}\text { "Advantages include being able to } \\
\text { study and continue working, } \\
\text { management of one's time and being } \\
\text { able to be close to one's family." }\end{array}$ & $\begin{array}{l}\text { "Very clear and specific. They } \\
\text { were easy to comprehend. They } \\
\text { were presented in simple English, } \\
\text { which most people can easily } \\
\text { understand." }\end{array}$ \\
\hline Utilization of study packages & $\begin{array}{l}\text { "Advantages include being able to } \\
\text { study and continue working, } \\
\text { management of one's time and being } \\
\text { able to be close to one's family." }\end{array}$ & $\begin{array}{l}\text { "They were clear and specific and } \\
\text { most of them targeted." }\end{array}$ \\
\hline $\begin{array}{l}\text { Delivery of all study materials } \\
\text { at the beginning }\end{array}$ & $\begin{array}{l}\text { "Advantages include being able to } \\
\text { study and continue working, } \\
\text { management of one's time and being } \\
\text { able to be close to one's family." }\end{array}$ & $\begin{array}{l}\text { "It was well done and helped } \\
\text { students to study the module } \\
\text { content in time, assisted in the } \\
\text { writing of assignments and } \\
\text { examinations." }\end{array}$ \\
\hline Self-directed learning & $\begin{array}{l}\text { "Advantages include being able to } \\
\text { study and continue working, } \\
\text { management of one's time and being } \\
\text { able to be close to one's family." }\end{array}$ & $\begin{array}{l}\text { "It helped me to create my own } \\
\text { time for studying, research, } \\
\text { assignment and social issues." }\end{array}$ \\
\hline Week - end school sessions & $\begin{array}{l}\text { "Advantages include being able to } \\
\text { study and continue working, } \\
\text { management of one's time and being } \\
\text { able to be close to one's family." }\end{array}$ & $\begin{array}{l}\text { "helped me to ask questions of } \\
\text { issues I found difficult, helped me } \\
\text { to get a summary of the module } \\
\text { from an expert tutor." }\end{array}$ \\
\hline Regional campuses & $\begin{array}{l}\text { "Advantages include being able to } \\
\text { study and continue working, } \\
\text { management of one's time and being } \\
\text { able to be close to one's family." }\end{array}$ & \\
\hline $\begin{array}{l}\text { Individualized guidance and } \\
\text { counseling }\end{array}$ & $\begin{array}{l}\text { "ODLA students face a lot of challenges } \\
\text { as they try to do their studies and work } \\
\text { at the same time/concurrently. Conflict } \\
\text { arises from the work place and within } \\
\text { the family." }\end{array}$ & $\begin{array}{l}\text { "Helped me to be focused on my } \\
\text { studies. They helped to know how } \\
\text { I can make best use of my study } \\
\text { time at home." }\end{array}$ \\
\hline $\begin{array}{l}\text { Use of multi - media in } \\
\text { instruction and communication }\end{array}$ & & $\begin{array}{l}\text { "It helped me to communicate with } \\
\text { my tutors on any issues } \\
\text { concerning my study. I also got } \\
\text { information concerning } \\
\text { registration, fees, sessional } \\
\text { results, examination dates, etc." }\end{array}$ \\
\hline Fees payment arrangements & & $\begin{array}{l}\text { "They were suitable for people of } \\
\text { various socio-economic status. } \\
\text { Those who could not pay the full } \\
\text { amounts were allowed to pay in } \\
\text { installments." }\end{array}$ \\
\hline
\end{tabular}

Likewise, individualized counseling is highly valued by participants because "ODLA students face a lot of challenges as they try to do their studies and work/concurrently" (see Table 2).

The data in Table 3 reveal the broad variety of knowledge and understandings the participants claim to have gained from the SPED programme. This knowledge can be classified in three categories, namely mastery of a technical vocabulary, understanding of the causes of learning disabilities, knowledge of types of disabilities, prevalence of disabilities in any given class, the expectations disabled pupils have on the teacher and diagnostic knowledge, knowledge of potential interventions and strategies that the teacher may use (see Table 3).

Below is a summary list of responses by the participants to the question: "What new knowledge did you acquire from the SPED program you studied?" 
Table 3: Substantive knowledge gained from the Special Education Degree (SPED) program (From interviews conducted on 26 January 2013).

\begin{tabular}{|c|c|c|}
\hline Knowledge category & Participant D & Participant E \\
\hline Know-what & $\begin{array}{l}\text { "I gained knowledge about the } \\
\text { causes of learning disabilities } \\
\text { which happen to be largely } \\
\text { environmental and biological." }\end{array}$ & $\begin{array}{l}\text { "Knowledge about disability issues } \\
\text { and special needs education." }\end{array}$ \\
\hline Know-what & $\begin{array}{l}\text { "I have knowledge that the learning } \\
\text { disabilities range from mild to } \\
\text { profound." }\end{array}$ & $\begin{array}{l}\text { "Special methods and equipment } \\
\text { used in teaching pupils with } \\
\text { disabilities, or special needs." }\end{array}$ \\
\hline Know-what & $\begin{array}{l}\text { "I do understand that there is a } \\
\text { whole host of Learning Disabilities } \\
\text { ((LD) that include dyscalculia, } \\
\text { disgraphia, disorthographia, } \\
\text { dyslexia." }\end{array}$ & $\begin{array}{l}\text { "Insights and understanding of the } \\
\text { assessment, counseling and } \\
\text { rehabilitation of children with } \\
\text { disabilities." }\end{array}$ \\
\hline Know-why & $\begin{array}{l}\text { "My knowledge of disability has } \\
\text { dispelled all myths that I previously } \\
\text { held about disability." }\end{array}$ & \\
\hline Know-how & $\begin{array}{l}\text { "I have learned to differentiate } \\
\text { between children with LDs and } \\
\text { those that have mental } \\
\text { retardation." }\end{array}$ & $\begin{array}{l}\text { "Theory and practical issues about } \\
\text { specific disabilities and categories } \\
\text { gearing impairment, visual } \\
\text { impairment, learning disabilities, } \\
\text { physical and motor disabilities, } \\
\text { etc." }\end{array}$ \\
\hline Know-what & $\begin{array}{l}\text { "I am aware that pupils with LDs } \\
\text { form the bulk of any given } \\
\text { classes." }\end{array}$ & $\begin{array}{l}\text { "Insights about the impact of } \\
\text { disability upon an individual." }\end{array}$ \\
\hline Know-that & $\begin{array}{l}\text { "I have the knowledge that LDs } \\
\text { can never be completely } \\
\text { eradicated, but can only be } \\
\text { reduced." }\end{array}$ & $\begin{array}{l}\text { "Various forms of interventions that } \\
\text { can be applied to help children } \\
\text { with special needs." }\end{array}$ \\
\hline Know-what & $\begin{array}{l}\text { "LDs usually co-exist with other } \\
\text { exceptionalities." }\end{array}$ & \\
\hline Know-that & $\begin{array}{l}\text { "Pupils with LDs may demand } \\
\text { more of the teacher's attention } \\
\text { than other groups of children." }\end{array}$ & $\begin{array}{l}\text { "Insights about the impact of } \\
\text { disability upon an individual." }\end{array}$ \\
\hline Know-why & $\begin{array}{l}\text { "I have learned that the level and } \\
\text { nature of intervention towards } \\
\text { children with disabilities depends } \\
\text { on the severity of the disability a } \\
\text { child has." }\end{array}$ & $\begin{array}{l}\text { "The ZOU SPED program } \\
\text { transformed me from a } \\
\text { knowledgeable person to a well- } \\
\text { informed, knowledgeable } \\
\text { understanding person concerning } \\
\text { disability issues." }\end{array}$ \\
\hline Know-why & & $\begin{array}{l}\text { "I had negative attitudes towards } \\
\text { people with disabilities due to lack } \\
\text { of knowledge, but now it has } \\
\text { changed." }\end{array}$ \\
\hline Know-why & & $\begin{array}{l}\text { "I thought ODLM programs were } \\
\text { looked down upon, but it turned } \\
\text { out to be the opposite since I was } \\
\text { uplifted professionally by my ZOU } \\
\text { SPED degree." }\end{array}$ \\
\hline
\end{tabular}

More significantly, the SPED program has, according to this participant "... dispelled all the myths that I previously held about disabilities". Overcoming cultural superstition constitutes great gain indeed for the two female participants. As Mbangwana $(2011,391)$ observed: “A typical African woman, for example, would not like to have anything to do with a disabled child".

The next section examines perceived skills and competences gained through the SPED programme by the two participants. 
From the data displayed in Table 4, specific skills and competencies gained can be identified. These can be grouped into the following categories:

- diagnostic techniques for identifying various forms of disabilities,

- $\quad$ analytical skills and procedures that may be applied individually to kids with disabilities,

- the application of different application counseling procedures models,

- the application of multi-disciplinary and trans-disciplinary approaches, and

- $\quad$ steps or procedures to be followed from the identification to the placement of children with disabilities (see Table 4).

The responses listed below were elicited from two questions: "Which specific skills and competences did you gain from SPED? How proficient are you in applying these skills in a classroom context?"

Table 4: New skills and capacities acquired from the SPED program (Interviews conducted on 9 February 2013)

\begin{tabular}{|c|c|c|}
\hline Skill aspect & Participant D & Participant E \\
\hline $\begin{array}{l}\text { Diagnostic skills } \\
\text { Technical-know-how } \\
\text { Procedural knowledge }\end{array}$ & $\begin{array}{l}\text { - "I have learned how to task analyze skills to } \\
\text { be taught to children with disabilities." } \\
\text { "I am equipped with skills and techniques to } \\
\text { deal with children with learning disabilities." } \\
\text { - I have learned how to apply the chaining } \\
\text { technique in teaching children with } \\
\text { disabilities." } \\
\text { "I have acquired knowledge on how to use } \\
\text { prompts in teaching the children in } \\
\text { question." } \\
\text { "I have knowledge of using different } \\
\text { counseling procedures on pupils with } \\
\text { disabilities, depending on the type of } \\
\text { disability, severity and age of the child." } \\
\text { "I have knowledge of applying the multi- } \\
\text { disciplinary, trans-disciplinary approaches in } \\
\text { dealing with issues of disability." } \\
\text { "I know the procedures to be followed from } \\
\text { the identification to placement of children } \\
\text { with disabilities." } \\
\text { "I have learned to adhere to the instructional } \\
\text { hierarchy when teaching a child with a } \\
\text { disability." } \\
\text { "I have learned how to include children with } \\
\text { disabilities in the regular school/class." }\end{array}$ & $\begin{array}{l}\text { - } \quad \text { Teaching children with } \\
\text { visual impairment-able to } \\
\text { transcribe Braille and write } \\
\text { Braille." } \\
\text { - } \quad \text { Ability to present a paper } \\
\text { and make a write up." } \\
\text { "Ability to formulate } \\
\text { Individual Education Plan } \\
\text { for each needy student and } \\
\text { teach accordingly." } \\
\text { "Ability to identify children } \\
\text { with special needs, screen, } \\
\text { or refer for further } \\
\text { assessment." }\end{array}$ \\
\hline
\end{tabular}

The six groups of skills the participants claim to have acquired from the SPED program compare very well with the recommended skill development program for Special Education teachers suggested by the Pennsylvania Special Education program guidelines (Pennsylvania Department of Education 2006) which prescribed similar skills in the training of special 
education teachers.

The data in Table 5 suggest a number of personal psycho-social and economic gains which were obtained by participants by completing the SPED program. They include, among others, the following: promotion to headship of the remedial department in the school, professional upgrading, improved social, financial, and academic status.

Overall, the program studied appears to have impacted positively on the participants' selfesteem and emotional well-being (see Table 5).

The comments below were in response to the question: "What changes in personal circumstances, beliefs and attitudes have you experienced as a result of completing your SPED program?”

Table 5: Personal changes engendered by the SPED program (16 February 2013)

\begin{tabular}{|c|c|c|}
\hline Change aspect & Participant D & Participant E \\
\hline Career advancement & $\begin{array}{l}\text { "I have been made head of the } \\
\text { remedial department in my } \\
\text { school." }\end{array}$ & $\begin{array}{l}\text { "ODL uplifted me from the grassroots to a very } \\
\text { prominent position which I never dreamt of } \\
\text { initially. It enabled me to shape my life and to } \\
\text { acquire degree programs which were just meant } \\
\text { for a few individuals before ZOU's } \\
\text { establishment." }\end{array}$ \\
\hline Personal growth & $\begin{array}{l}\text { "My self-esteem has been } \\
\text { greatly boosted." }\end{array}$ & $\begin{array}{l}\text { "SPED programme helped to uplift my } \\
\text { professional status from being a primary school } \\
\text { teacher to an assistant lecturer." }\end{array}$ \\
\hline \multirow[t]{2}{*}{ Cultural emancipation } & $\begin{array}{l}\text { "My knowledge of disability has } \\
\text { dispelled all the myths that I } \\
\text { previously held about disability." }\end{array}$ & $\begin{array}{l}\text { "The ZOU SPED programme transformed me } \\
\text { from a non-knowledgeable person to a well- } \\
\text { informed, knowledgeable, understanding person } \\
\text { concerning disability issues." }\end{array}$ \\
\hline & $\begin{array}{l}\text { "I can now interact at any level } \\
\text { with people with disabilities." }\end{array}$ & $\begin{array}{l}\text { "The ZOU SPED programme transformed me } \\
\text { from a non-knowledgeable person to a well- } \\
\text { informed, knowledgeable, understanding person } \\
\text { concerning disability issues." }\end{array}$ \\
\hline Change in social status & $\begin{array}{l}\text { "Socially again, I can co-relate } \\
\text { with other professionals and } \\
\text { stakeholders involved in } \\
\text { disabilities issues." }\end{array}$ & $\begin{array}{l}\text { "I recommend that women should take up the } \\
\text { SPED programme without fear and anxiety } \\
\text { because it's less costly in terms of tuition fees, } \\
\text { one studies in the comfort of your home as a } \\
\text { result, the family will not miss you much." }\end{array}$ \\
\hline $\begin{array}{l}\text { Emotional growth and } \\
\text { attitudinal change }\end{array}$ & $\begin{array}{l}\text { "Emotionally, my sympathy for } \\
\text { people with disabilities has } \\
\text { turned into empathy-they do not } \\
\text { need my sympathy." }\end{array}$ & $\begin{array}{l}\text { "I had negative attitudes towards people with } \\
\text { disability due to lack of knowledge but now it has } \\
\text { changed." }\end{array}$ \\
\hline $\begin{array}{l}\text { Academic and } \\
\text { professional } \\
\text { development }\end{array}$ & $\begin{array}{l}\text { "Academically and } \\
\text { professionally, I have made a } \\
\text { giant leap forward." }\end{array}$ & $\begin{array}{l}\text { "The programme is beneficial because it will } \\
\text { uplift your professional status. It also helps me to } \\
\text { improve in the execution of duties." }\end{array}$ \\
\hline Financial gain & $\begin{array}{l}\text { "Materially, my salary will } \\
\text { increase by at least } 40 \text { US } \\
\text { dollars." }\end{array}$ & \\
\hline Self-interest & & $\begin{array}{l}\text { "Programme was in line with my area of interest- } \\
\text { working with less privileged members of } \\
\text { society." }\end{array}$ \\
\hline
\end{tabular}

\section{DISCUSSION OF FINDINGS}

The results of the study indicate two important reasons why the ODLA has become the preferred method of professional upgrading by adult learners in Zimbabwe. These reasons can 
be better understood and explained through Doyle and Ponder's (1977) Practicality Ethic Theory and Daniel's (2008) conceptualization of the ODLA as a revolutionary technology respectively.

The first reason relates to the congruency between the ODLA and adult learners' value systems (Doyle and Ponder 1977). In this respect, the ODLA is attractive among adult learners who wish to upgrade their qualifications because it addresses their practical concerns (Doyle and Ponder 1977). These practical concerns range from psycho-social fulfilment, economic empowerment and professional upgrading. From a personal psycho-social perspective, the ODLA affords previously marginalised rural teachers with opportunities to uplift their academic and social statuses by giving them the freedom to choose programmes of their own preference. Economically, the qualifications obtained through the ODLA enable the graduates to gain promotion and advance their careers in the civil service. In the context of a chronically depressed socio-economic environment, participants in this study would regard enrolling with the ODLA as economically justified, prudent and judicious decision-making.

More profoundly, the results of the study revealed that the ODLA afforded participants to switch careers and upgrade their professional qualifications. For one of the participants, the ODLA has enabled her to scale the dizzying height of the academic ladder. In view of this, participants have become advocates and living testimonies of the empowerment and transformation flowing from ODLA educational provision.

The second important reason relates to the efficacy and effectiveness of the ODLA as a revolutionary technology in education in terms of providing accessible and affordable university education to previously marginalised groups (Daniel 2010). The adoption and implementation of business or entrepreneurial principles in the Zimbabwe higher education sector has singularly given the ODLA comparative advantage and market dominance over CBUs (contact-based universities) due to several factors.

The first factor relates to the incorporation of business principles in university education delivery. The inaugural Vice-Chancellor of the ZOU had this to say on the matter "... the ZOU has to be market and product driven so as to create new markets for our programs and raise education standards in the sector especially in materials production. In the process the ZOU intends to redefine student expectations or even increase the pace of industry cycles in the higher education provision in this country" (Dzwimbo 2000, 101). In this regard, macro- and micro-level marketing and program development strategies have been instituted as customer catch plans.

Another key factor enticing participants to gravitate towards the ODLA hinges on matters of accessibility and affordability. In a depressed socio-economic environment, these two 
arguably constitute the major drawing card of ODLA provision.

Accessibility relates to unrestricted entry to a degree programme of one's choice whereas affordability refers to a personalised fee structure and payment arrangements. The ZOU has pioneered the payment of university tuition in instalments as a way of allowing more students on low income to enrol for their studies. The issue of access is further articulated in temporal and spatial arrangements embedded in the instructional design and delivery of ODLA programs such as accessing programs at regional, district and ward levels (Chabaya 2013). This finding corroborates Mugadzaweta and Benza's (1999) studies which reported ODLA students' aversion to travelling long distances to study centres.

Finally, the self-study package features prominently as a key inducement for rural teachers to opt for the ODLA. The participants indicated that the learning package provided them with flexible opportunities and options for balancing work commitments with study. This finding is consistent with the research literature that suggests that the glossy eye-catching materials or programme packages are more than study materials, they articulate and express the ODLA educational ideology and principles (Perry 1976; Daniel 1998). More specifically, the customized package according to these writers, constitute the customer bait or student catch plan in terms of their conceptualization, designing and packaging.

At the psycho-social level, the purpose built package appears to have been effective in articulating the professionally and personal needs of the participant. In this study, the participants claim to have acquired new knowledge, skills and competences in terms of a substantive knowledge base, a repertoire of skills and positive attitudes towards students with disabilities (see Tables 2 and 3). This finding is consistent with the research literature which suggests that effective upgrading programs should impact positively on teacher epistemologies and attitudes (Danaher 2010).

\section{CONCLUSION}

To conclude, the results of this study indicate that participants have been drawn to the ODLA by several practical benefits, namely personal and professional growth. These findings have a number of implications for teacher upgrading policies particularly in developing countries.

First, from a national perspective, the potency of the ODLA provision to upgrade teacher competences cost-effectively is welcome in several respects. Upgrading teachers' capacities particularly in the Special Education program is a boon in terms of providing a diversified school curriculum and improving access to quality education by marginalized groups of pupils with learning disabilities. Teacher empowerment would enhance the implementation of government policy on inclusion which Mudyahoto and Mswazie' s (2013) studies had indicated 
as moribund in Masvingo urban primary schools.

Second, from a teacher educator and training perspective, the positive impact and effectiveness of the ODLA programme may hopefully provide useful insights and lessons into designing high impact initial teacher education programs through consultative processes. CBUs have been accused of designing teacher education programs which are whimsical and detached from the realities of students and the local communities (Mswazie 2013).

Finally, the flexibility and scalability embodied in ODLA instructional design provides governments in developing countries with the technology for teachers to upgrade, revamp, and up-date their teacher education systems more cheaply in line with modern trends of teacher professional development. In this regard, the ODLA has proved itself as a revolutionary technology in higher education reforms (Daniel 1998).

\section{REFERENCES}

Danaher, P. A. 2010. Contemporary research on distance education through open and distance learning. In Perspectives on distance education. Teacher education through distance and open learning, ed. P. A. Danaher and A. Umar. Vancouver: Common Wealth of Learning.

Daniel, J. 1998. Mega universities and knowledge media technology strategies for higher education. London: Kogan Paul.

Daniel, J. S. 2008. Vital speeches of the day. LXXIV (5): 214-216.

Daniel, J. 2010. Mega-schools, technology and teachers. Achieving education for all. Megaschools technology and teachers. London: Routledge.

Doyle, W. and G. E. Ponder. 1977. The practicality ethic in teacher decision-making. www.mendeley. com/research/practicality-ethic-teacher-decisionmaking/ (Accessed 8 December 2012).

Dzwimbo, K. 1991. The transition state and the dialectics of educational transformation in the third world: The case of Zimbabwe. International Studies in the Sociology of Education 1(1-2): 43-58).

Dzwimbo, K. 2000. The African University in the $21^{\text {st }}$ century: The quest for self-financing in the Zimbabwe Open University. The Zimbabwe Journal of Educational Research 12(3): 96-112.

Fullan, M. 1991. The new meaning of educational change. $2^{\text {nd }}$ Edition. London: Casell Education Limited.

Kurasha, P. 2003. Access to tertiary education as a national strategy for development: The Zimbabwe Open University case. A case study prepared for regional training conference on improving education in sub-Saharan Africa. Things that work. Acccra. September 23 -24.

Mbangwana, M. 2011. Assitive techniques and technology for teachers of disabled persons. In Handbook of African Educational Theories and Practices, ed. A. Nsamenang and T. M. Tchombe. Bamenda: Human Resource Development Centre.

Mswazie, J. 2013. Reconceptualizing the design and delivery of teacher preparatory programmes: Insights from Zimbabwe. International Journal of Asian Sciences 3(2): 386-404.

Mudyahoto, T. and J. Mswazie. 2013. An assessment of the effects of local cultures on sports participation by disabled pupils in Masvingo urban primary schools in Zimbabwe. International Journal of Asian Social Science 3(2): 370-385 
Mugadzaweta, J. and T. Benza. 1999. Distance education in Zimbabwe. http://www.col.org/ forum/Pcfpapers (Accessed 16 March 2012).

Pennyslvania Department of Education. 2006. Special education programme guidelines. http://www.wspsd.k12.pa.us/Tittlepagecontent/PDEqualificationsteacher.pdf: 14-26. (Accessed 24 April 2013).

Perry, W. 1976. Open University. A personal account by the $1^{\text {st }}$ Vice Chancellor. Hertfordshire: The Open University Press.

UNESCO. 2002. Open and Distance Learning. Trends, policy and strategy considerations http://unesco.unesco.org/images/001284/128463e.pdf (Accessed 24 December 2012).

UNESCO. 2007. Education for all by 2015. Will we make it? Global Monitoring Report. Paris: UNESCO.

UNESCO. 2009. ICT in teacher education http://uescodoc.unesco.org/images/0019/001936/ 193658e.pdf (Accessed 10 March 2012). 